\title{
The Quality of Milk Chocolate Bars by Substitution of Cocoa Butter, Milk Powder and Lecithin Soya - A Preliminary Study
}

\author{
Hasni Dian" and Rahmad Dedy ${ }^{*}$ \\ \# Agricultural Product Technology, Syiah Kuala University, Tgk Hasan Krueng Kalee 3 Darussalam, Banda Aceh, 23111, Indonesia \\ E-mail: hasni.dian84@gmail.com \\ * Chemical Engineering Department, Academy of Industrial Technology Padang, Jl. Bungo Pasang Tabing, Padang, Indonesia \\ E-mail: rahmad.dedy@gmail.com
}

\begin{abstract}
Milk chocolate is most important products of confectionary that are well-known for its consumer, and a precious ended product in entirely value added chain in cacao. In chocolate industry, each ingredient plays an important role in product quality. This research aims to assess the possibility of substitution of cocoa butter and its impact on physiological appearance and sensory quality hedonically, to formulate optimum formulation of palm oil as cocoa butter substitute $(0 \%$; $10 \%$; $20 \%)$, milk powder $(0 \%$; $10 \%$; $20 \%)$ and lechitin $(0.5 \% ; 1 \% ; 1.5 \%)$. Melting point and attribute preferences test were conducted for aroma, texture and flavour. Melting point were indicated that interaction within palm oil replacement and milk powder had significant impact to lowering the melting point of milk chocolate, whilst addition of lechitin up to $1 \%$ also decreased the melting point range. Attribute preference test from 40 untrained panellists evaluated that palm oil replacement up to $20 \%$ had improved the panellists preferences for aroma whereas it had contradiction effect for texture. For taste, additional milk powder up to $20 \%$ definitely enhances the taste preferences. Partial Least Regression shows that palm oil replacement had negative effect on aroma and flavour of milk chocolate, whereas it has positive impact on texture. The increase of additional of milk powder plays an negative impact as well to panellist perceptions towards aroma, flavour and texture. Lechitin as emulsifier influences significantly towards the aroma and flavour of milk chocolate, but not for texture. Sensory evaluation revealed that milk chocolate made from $10 \%$ palm oil substitution, $10 \%$ milk powder and $1 \%$ lechitin as more accepted hedonically as conventional milk chocolate.
\end{abstract}

Keywords - milk chocolate, palm oil, milk powder, lechitin, cocoa butter

\section{INTRODUCTION}

Cacao (Theobroma cacao) is one of primary commodity for Indonesian economic. As the third largest production after Pantai Gading and Ghana, Indonesia produced 490 million tonnes [1], which majorly owned and processed by small scale farmers.

Aceh and West Sumatra Provinces are two largest cocoa production with \pm 12.462 million tonnes produced in 32.108 ha in Aceh, whilst 20.881 million tonnes cacao beans produced in 48,353 ha in West Sumatera [2]. $80 \%$ of this massive production is exported, where the rest is locally distributed and sold in form of bean.

In recent years there are many studies focussed on gaining added value of cacao bean by studying the making process all cocoa derivatives products in order to understand the know-how and technical details which are fully suitable for local manufacturer in Aceh and West Sumatera.

Chocolate counts as final product of cocoa bean, where both provinces above as central production of cocoa bean are still lack of presence of chocolate manufacturers. As most knowledgeable product of cacao, as the most craved food [3], confectionary product with unique taste [4] and has health benefit [5]. Chocolate defines as the homogenous combination of cocoa powder, cocoa butter with milk powders, sugars, and/or sweeteners and other additives [6]. Chocolate is an emulsion, where during manufacture, refining and conching have effects in particle size, consistency and sensory qualities [7].

Cocoa butter, which are mostly contained by saturated stearic (34\%) and palmetic (27\%) fatty acid and monounsaturated oleic acid (34\%) [8], is the most costly raw material in chocolate manufacturer. Some vegetable fats, consider to have similar composition can be added as substitution in any proportion to chocolate without causing a significant effect on texture (Talbot 1999) [9] such as palm olein. In this present study substitution of palm oil are used $0 \%, 10 \%$ and $20 \%$ of $\mathrm{w} / \mathrm{w}$.

Milk chocolate is often used milk crumb and or milk powder. Recent studies reported that milk powder is being 
used at about $20 \% \mathrm{w} / \mathrm{w}$ in formulation, and have clear effect the sensory characteristics of the final product and processing behaviour $[10,1]$.

To our knowledge, there are any publications and/or researches regarding on manufacturing of chocolate for local manufacturer in small scale production in terms of low capital input. In our opinion in order to gain knowledge and collect all general information in chocolate manufacturing it would be interesting to study in depth the formulation of raw material of chocolate towards physical characteristics and panellist acceptances of milk chocolate. For this purpose in the present work palm olein is used as substitution of cocoa butter by aiming to reach the cost efficiency, concentration of milk powder and lecithin are evaluated based on melting points, cracking power and hedonic test.

\section{MATERIALS AND METHODS}

\section{A. Materials}

Material $3.5 \mathrm{~kg}$ cocoa powders are obtained from brand van Houten, $3 \mathrm{~kg}$ palm olein are obtained from brand Blueband, sugars, skim milk powder brand Prolac, and vanilli. Lecithin soya and cocoa butter are obtained from Bratachem Co, Medan - North Sumatera.

\section{B. Preparation of chocolate samples}

The ingredients were used in milk chocolate as written by Beckett (1999) [8] with formulation of $41 \%$ sugars, $6 \%$ cocoa powder, $35 \%$ cocoa butter, $20 \%$ milk powder and lechitin soya. Samples were prepared by substituting cocoa butter at level $0 \%, 10 \%$ and $20 \%$, addition of milk powder $0 \%, 10 \%$ and $20 \%$ and lechitin $0.5 \%, 1 \%$ and $1.5 \%$. The quantities of the ingredients of all formulations are shown in Table 1. The milk chocolate production started from mixing, conching, tempering with water bath, cooling and packaging.

TABLE I

FORMULATION OF MILK CHOCOLATE

\begin{tabular}{|l|c|c|c|}
\hline Ingredients & $\mathbf{1}^{\text {st }}$ Level & $\mathbf{2}^{\text {nd }}$ Level & $\mathbf{3}^{\text {rd }}$ Level \\
\hline Palm Olein & $0 \mathrm{~g}$ & $50 \mathrm{~g}$ & $100 \mathrm{~g}$ \\
\hline Cocoa Butter & $175 \mathrm{~g}$ & $125 \mathrm{~g}$ & $75 \mathrm{~g}$ \\
\hline Milk Powder & $0 \mathrm{~g}$ & $50 \mathrm{~g}$ & $100 \mathrm{~g}$ \\
\hline Cocoa Powder & $30 \mathrm{~g}$ & $30 \mathrm{~g}$ & $30 \mathrm{~g}$ \\
\hline Sugars & $205 \mathrm{~g}$ & $205 \mathrm{~g}$ & $205 \mathrm{~g}$ \\
\hline Lechitin & $2.5 \mathrm{~g}$ & $5 \mathrm{~g}$ & $7.5 \mathrm{~g}$ \\
\hline
\end{tabular}

\section{Methods}

\section{1) Melting point.}

The method given by Ketaren [12] was applied for measuring the melting point of milk chocolate.

\section{2) Attributes Hedonic Test.}

The hedonic test examined the effects of formulation towards the aroma, flavour and texture of mix chocolate according to methods [13]. Milk chocolate bar were evaluated by 40 untrained panellists, samples kept at temperature $18^{\circ} \mathrm{C} \pm 2$ for $1 \mathrm{~h}$ before evaluation. Samples were served in white plastic plates; water and bread were provided for cleaning the palate between samples. Each panellist was asked to give a number from 1 (very dislike) to 5 (very like) on the hedonic scales.

Statistical analysis. Analysis of variance and Least Significant Difference test ( $\mathrm{p}<0.05$ ) was computed by SPSS 17.0, and the Partial Least Regression for attributes hedonic test was computed by Unscrambler 10.3.

\section{RESULTS AND DISCUSSIONS}

\section{A. Physical Appearance}

Melting point. Milk chocolate has temperature range for melting point, due to its polymorphic characteristics. The replacement of palm oil downsize the melting point, which might be occurred to cocoa butter has lower melting point $\left(30-35^{\circ} \mathrm{C}\right)$ than palm oil $\left(37-38^{\circ} \mathrm{C}\right)$ and milk powder $(40-$ $45^{\circ} \mathrm{C}$ ). Moreover, as expand as $\mathrm{C}$-chain, the melting point is decreasing with the double bond attached such as oleic acid (C18:1), as major triglycerides components of cocoa butter (38.2\%) palm oil $(34.61 \%)$ and milk fat (25.2\%). As circumstances, effect of replacement of palm oil and addition of milk powder is increasing of oleic acid which has an impact to the decrease of milk chocolate melting point.

Lechitin soya acts as emulsifier which maintains the polymorphic systems of chocolate are stable. Addition up $1 \%$ lechitin decreased the melting points, whilst the higher level has similar effect.

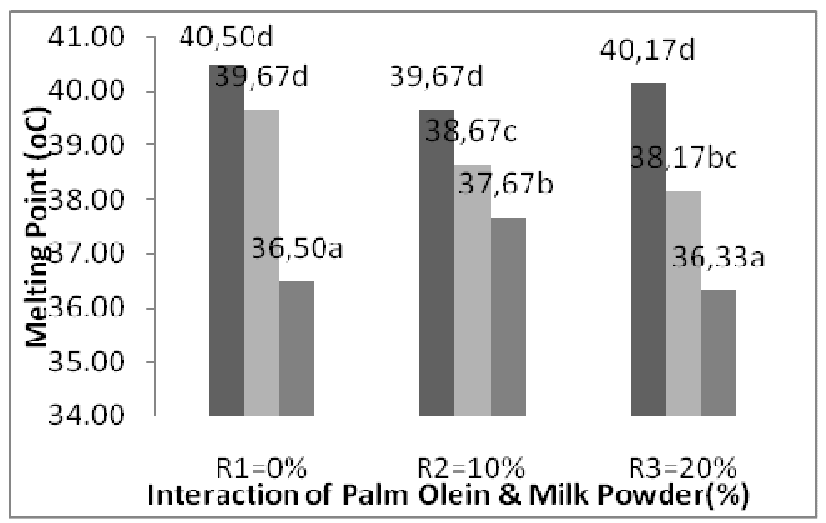

Fig. 1 Interaction Effect of Palm Oil \& Milk Powder towards melting points $(\mathrm{p}<0.05)$

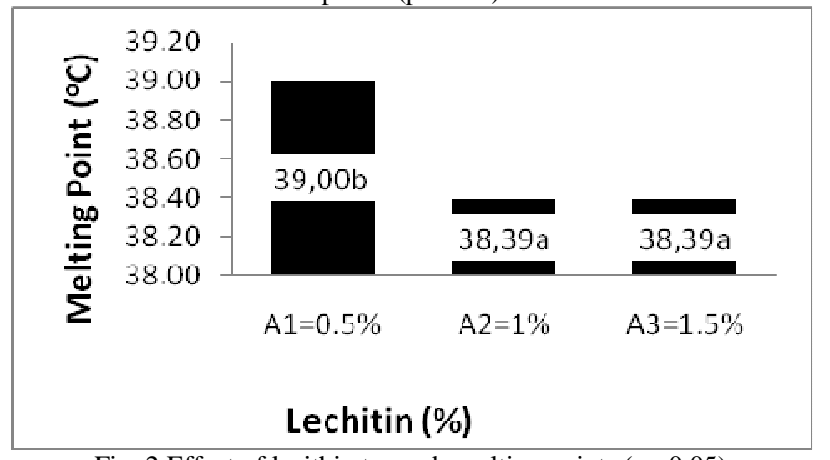

Fig. 2 Effect of lecithin towards melting points $(\mathrm{p}<0.05)$

\section{B. Attributes Hedonic Tests}

Attributes hedonic tests assessed 40 panellists responses towards sensory of milk chocolate, which are aroma, flavour and texture. Analysis of variance showed that the increasing level of palm oil used in milk chocolate recipes enhances the level of panellist preferences, since $20 \%$ of palm oil 
substitutes gained the highest score (3.28). The range of aroma of milk chocolate were around 2.18-3.42 (dislike to just right). Moreover, palm oil substitute also influenced the texture of milk chocolate where the higher levels of palm oil substitute (20\%) panellist responses were the lowest (2.53), where the panellists preferences in range of 2.35-3.24 (dislike to just right). Addition of milk powder up to $20 \%$ lowered the panellist preferences towards flavour (2.84). Panellist responses towards flavour in range of 2.52-3.42 (dislike to just right).

TABLE II

EFFECT OF PALM OIL SUBSTITUTION TO AROMA AND TEXTURE OF MILK CHOCOLATE

\begin{tabular}{|l|c|c|c|c|}
\hline Level Treatment & \multicolumn{2}{|c|}{ Aroma } & \multicolumn{2}{c|}{ Texture } \\
\hline Palm Oil 0\% & $2.73^{\mathrm{a}}$ & \pm 0.32 & $2.69^{\mathrm{ab}}$ & \pm 0.33 \\
\hline Palm Oil 10\% & $3.17^{\mathrm{b}}$ & \pm 0.16 & $2.78^{\mathrm{b}}$ & \pm 0.22 \\
\hline Palm Oil 20\% & $3.28^{\mathrm{b}}$ & \pm 0.11 & $2.53^{\mathrm{a}}$ & \pm 0.19 \\
\hline
\end{tabular}

TABLE III

EFFECT OF MILK AROMA TO FLAVOUR OF MILK CHOCOLATE

\begin{tabular}{|l|l|l|}
\hline Level Treatment & \multicolumn{2}{|c|}{ Flavour } \\
\hline Milk Powder 0\% & $3.07^{\mathrm{a}}$ & \pm 0.31 \\
\hline Milk Powder 10\% & $3.02^{\mathrm{b}}$ & \pm 0.18 \\
\hline Milk Powder 20\% & $2.84^{\mathrm{c}}$ & \pm 0.17 \\
\hline
\end{tabular}

Correlation loadings between treatments (palm oil substitute (A), milk powder (B) and lechitin (C)) as X variables where each hedonic attribute as $\mathrm{Y}$ variables (aroma, flavour and texture). This correlation loadings were computed for each variables. Fig 1 showed that X-variables have $33 \%$ explained variance and this percentage has power to successfully explain $55 \%$ of aroma as $\mathrm{Y}$ variable. Furthermore the two ellipses described the explained variance, by means the variation in data is described by the model. Fig 3 showed that explained variance of aroma is $55 \%$, where the rest are noise. The outer ellipse is unit circle and indicated $100 \%$, whereas the inner ellipse indicates $50 \%$ of explained variance. Therefore in interpreting the result, the outer ellipse is assumed to have most important variables than the inner one.

Fig 4 showed that palm oil substitute (A) and lecithin (C) are on the similar ellipse with aroma (1), where milk powder (B) is in the inner circle. The position means that palm oil substitute and lecithin are correlated with texture. Fig 4 showed that lecithin was positively correlated, and palm oil substitute negatively correlated.

Fig 5 showed the correlation loadings within treatments and flavours. Treatments as $\mathrm{X}$ variables have $33 \%$ explained variances which have power to explain only $20 \%$ of flavour, where most $80 \%$ are noise. Fig 5 showed flavour was in inner circle, whilst milk powder (B) and lechitin (C) were in outer circle, as most influence factors. This means that addition of milk powder and lecithin were correlated to the flavour of milk chocolate. This explanation was supported by Table 2, whereas increase as the level of milk powder added, panellists preferences were also decreased. Fig 6 also explained that milk powder had negative correlation towards flavour, whilst lecithin was likewise. The addition of milk powder up to $20 \%$ seems to be over-dominated the flavour of milk chocolate. Panellists wrote that they felt "wax taste" for milk chocolate that added by $20 \%$ of milk powder.

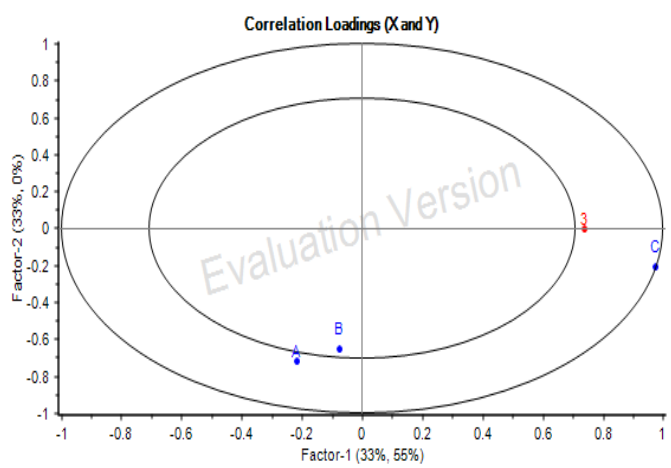

Fig. 3 Correlation loadings between treatments and aroma

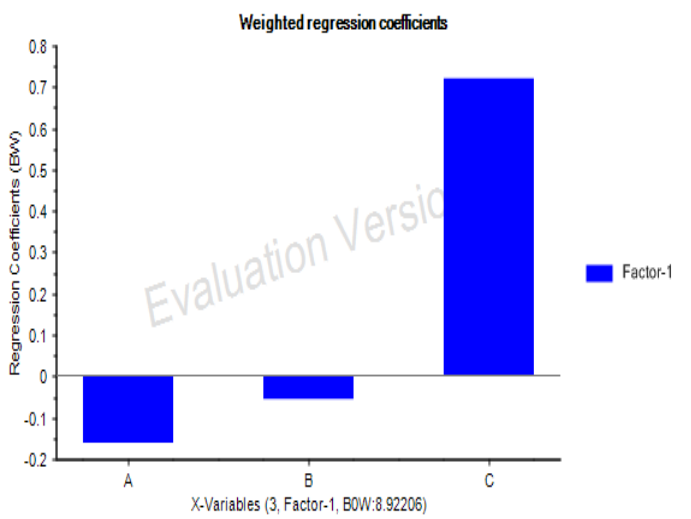

Fig. 4 Regression coefficients between treatments and aroma

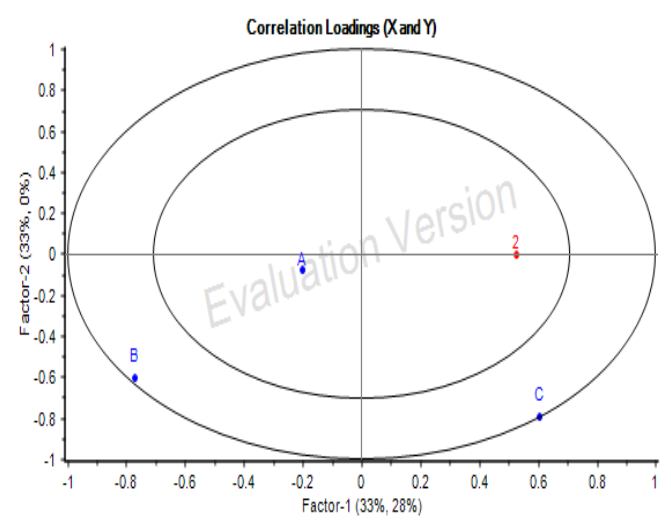

Fig. 5 Correlation loadings between treatments and flavour

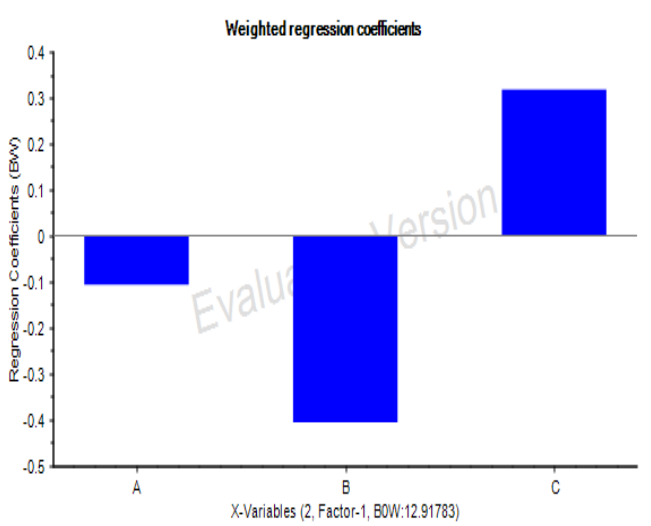

Fig 6 Regression coefficients between treatments and flavour 


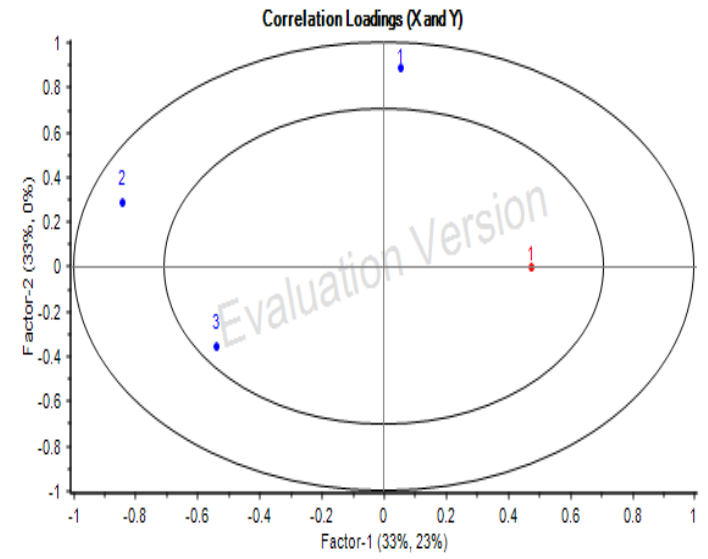

Fig. 7 Correlation loadings between treatments and texture

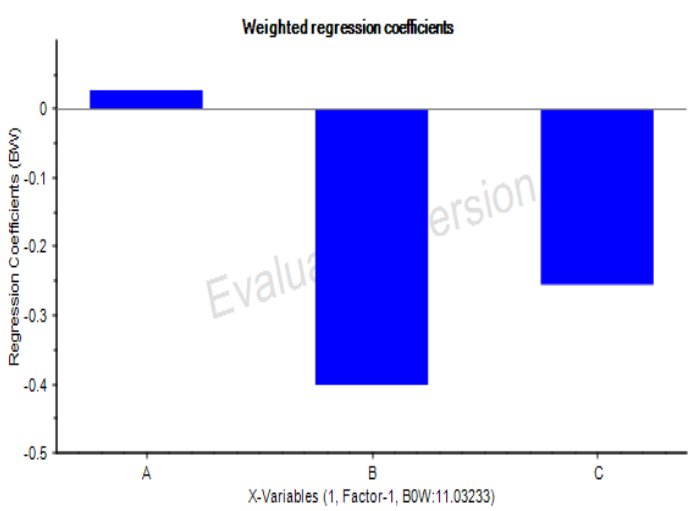

Fig. 8 Regression coefficients effects on aroma

Fig 7 illustrated that $X$ variables have $33 \%$ explained variables towards $27 \%$ of variables $\mathrm{Y}$, which was texture. Texture was in inner whilst palm oil substitute and milk powder were in outer circle. Moreover Fig 8 showed that milk powder correlated negatively towards texture, as same as described by Table 1 . Addition of milk powder up to $20 \%$ had impact of texture blooming, where the milk powder particles visually appeared on the surface of milk chocolate (Fig 9). Blooming is categorised as failure of stable emulsion. This might be occurred due to the fat contents within cocoa, palm oil and milk lipid were not well-homogenised. Blooming might be happened when the crystallisation rate of milk lipid during tempering was slower than cocoa butter, which caused the milk lipid destroyed chocolate emulsion. As an impact chocolate had oily surface as panellist named as wax tase and brittle texture [8].
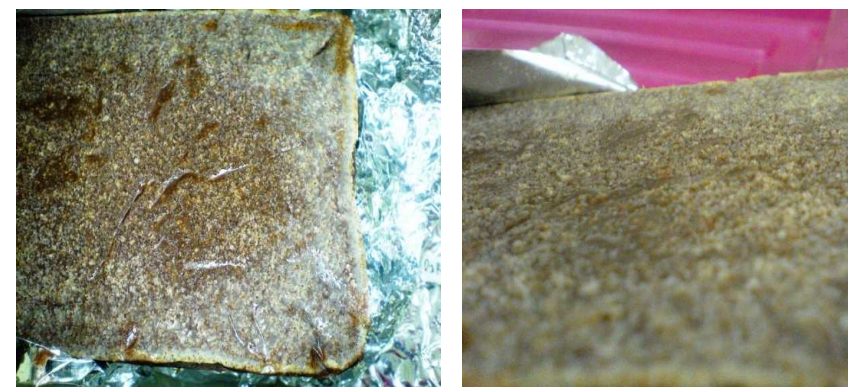

Fig. 9 Example of an unacceptable low-resolution image

\section{CONCLUSIONS}

Taken everything into consideration, the aims of this study to determine the optimum level of palm oil substitute, milk powder addition and lecithin by investigate its impact toards melting point and hedonic test of milk chocolate. Combinattion of $10 \%$ palm oil substitute, $10 \%$ milk powder and $1 \%$ lecithin analysed as the best formulation based on melting points and preferences attributes test in just right hedonic scale for aroma, flavor and texture. Partial Least Regression determined that the increasing level of palm oil substitute were negatively correlated towards aroma and flavor of milk chocolate, whilst increasing milk powder added had negatively correlated towards all of hedonic attributes. Lechitin as emulsifier influences significantly towards the aroma and flavour of milk chocolate, but not for texture.

\section{REFERENCES}

[1] International Cocoa Organization (ICCO). Global cocoa production, Available at: https://www.icco.org/statistics/production-andgrindings/ production.html. 2013

[2] Badan Pusat Statistik. Tabel Luas Perkebunan Menurut Propinsi dan Jenis Tanaman. Available at: https;//www.bps.go.id/linkTabelStatis/ view/id/1671. 2013.

[3] Hill, A.J., Heaten-Brown, L.. The experience of food craving: a prospective investigation in healthy women. Journal of Psychosomatic Research, Vol. 38, pp. 801-814, 1994.

[4] Chiva, M.. Cultural and psychological approaches to the consumption of chocolate. In: Knight, J. (Ed.), Chocolate, Cocoa, Health and Nutrition. Blackwell, Oxford, London, pp. 321-338, 1999.

[5] Serafini, M., Bugianesi, R., Maiani, G., Valtuena, S., De-Santis, S., Crozier, A.. Plasma oxidants from chocolate. Nature Vol. 424, pp. 1013-1018. 2003.

[6] El- kalyoubi, M., Khallaf., M.F. Abdelrashid., A., Mostafa., E.M. Original characteristics of chocolate - containing some fat replacer. Annalas of Agricultural Science. Vol(No): 56(2)., pp. 89-96. 2011.

[7] Afoakwa, E.O., Paterson, A., Fowler, M. Effects of particle size distribution and composition on rheological properties of dark chocolate. European Food Research and Technology, Vol 226, pp. 1259-1268, 2008.

[8] Beckett, S.T. Industrial Chocolate Manufacture and Use, 3rd. ed. Blackwell, Oxford, London. 1999.

[9] Talbot, G.. Chocolate temper. In: Beckett, S.T. (Ed.), Industrial Chocolate Manufacture and Use, 3rd ed. Oxford, Blackwell Science, London, pp. 218-230.1999.

[10] Franke, K., Heinzelmann, K. Structure improvement of milk powder for chocolate processing. International Dairy Journal. Vol.. 18,pp. 928-931. 2008

[11] Taylor, J.E., Van Damme, I., Johns, M.L., Routh, A.F., Wilson, D.I. Shear rheology f molten crumb chocolate. Journal of Food Science. Vol (No); 74 (2) pp, 55-61. 2009

[12] Ketaren, S. Pengantar Teknologi Minyak dan Lemak Pangan. Universitas Indonesia-Press, Jakarta. 1986.

[13] Meilgaard, M.C., Civille, G.V., and Caar, B.T. Sensory evaluation techniques. 4th eds. CRC Press. 2007. 